Retraction

\title{
Retracted: Effects of Scrambler Therapy in Patients with Failed Back Surgery Syndromes and Factors Associated with Depression Affecting Pain before and after the Therapy
}

\author{
Pain Research and Management
}

Received 3 December 2020; Accepted 3 December 2020; Published 2 February 2021

Copyright (c) 2021 Pain Research and Management. This is an open access article distributed under the Creative Commons Attribution License, which permits unrestricted use, distribution, and reproduction in any medium, provided the original work is properly cited.

Pain Research and Management has retracted the article titled "Effects of Scrambler Therapy in Patients with Failed Back Surgery Syndromes and Factors Associated with Depression Affecting Pain before and after the Therapy" [1]. Scrambler Therapy ${ }^{\circledR}$ is a registered trademark held by Prof. Giuseppe Marineo and may only be used to refer to approved medical devices, which does not include the Pain Jammer ENS-1140.

The authors do not agree with retraction.

\section{References}

[1] H. Byun, M. K. Oh, and C. H. Lee, "Effects of Scrambler Therapy in Patients with Failed Back Surgery Syndromes and Factors Associated with Depression Affecting Pain before and after the Therapy," Pain Research and Management, vol. 2020, Article ID 9342865, 6 pages, 2020. 